\title{
Genetics of Chickpea Resistance to Five Races of Fusarium Wilt and a Concise Set of Race Differentials for Fusarium oxysporum f. sp. ciceris
}

\author{
Kamal Dev Sharma, Weidong Chen, and Fred J. Muehlbauer, USDA-ARS Grain Legume Genetics and Physiol- \\ ogy Unit, Washington State University, Pullman 99164-6434
}

\begin{abstract}
Sharma, K. D., Chen, W., and Muehlbauer, F. J. 2005. Genetics of chickpea resistance to five races of Fusarium wilt and a concise set of race differentials for Fusarium oxysporum f. sp. ciceris. Plant Dis. 89:385-390.

Genetics of resistance in chickpea accession WR-315 to Fusarium wilt was investigated, and a concise set of differentials was developed to identify races of Fusarium oxysporum f. sp. ciceris. A population of $100 \mathrm{~F}_{7}$ recombinant inbred lines (RILs) from a cross of WR-315 (resistant) and C-104 (susceptible) was used to study genetics of resistance to races $1 \mathrm{~A}, 2,3,4$, and 5 of $F$. oxysporum f. sp. ciceris, and a population of $26 \mathrm{~F}_{2}$ plants from a cross between the same two parents was used to study inheritance of resistance to race 2. Segregations of the RILs for resistance to each of the five races suggest that single genes in WR-315 govern resistance to each of the five races. A 1:3 resistant to susceptible ratio in the $F_{2}$ population indicated that resistance in WR-315 to race 2 was governed by a single recessive gene. A race-specific slow disease progress reaction was observed in chickpea line FLIP84-92C(3) to infection by race 2, a phenomenon termed as slow wilting, that is different from previously reported late wilting with respect to latent period, disease progress rate, and final disease rating. Twenty-nine germ plasm lines (27 Cicer arietinum and two C. reticulatum) including previously used differentials were evaluated for their reactions to infection by the five races. Only eight of the 29 germ plasm lines differentiated at least one of the five races based on either resistant or susceptible reactions, whereas the remaining germ plasm lines were either susceptible or resistant to all five races or differentiated them by intermediate reactions. A concise set of eight chickpea lines comprised of four genotypes and four $\mathrm{F}_{7}$ RILs with vertical resistance was developed as differentials for race identification in F. oxysporum f. sp. ciceris. These differential lines were characterized by early appearance of wilt symptoms, and clear and consistent disease phenotypes based on no wilt or 100\% wilt incidence, which offers important improvements over previously available differential sets and provides more precise and unambiguous identification of the races.
\end{abstract}

Additional keywords: chickpea wilt, single gene resistance, vertical resistance

Fusarium wilt, caused by Fusarium oxysporum Schlechtend.:Fr. f. sp. ciceris (Padwick) Matuo \& K. Sato, is one of the most important biotic stresses of chickpea (Cicer arietinum L.) and has the potential to cause $100 \%$ yield losses. An annual loss in chickpea grain yield of about 10 to $15 \%$ has been reported for this disease (8). The disease is prevalent in the Indian subcontinent, Ethiopia, Mexico, Spain, Tunisia, Turkey, and the United States $(5,17,31)$. F. oxysporum f. sp. ciceris is a vascular pathogen that perpetuates in seed and soil,

Corresponding author: W. Chen

E-mail:w-chen@wsu.edu

Current address of K. D. Sharma: Advanced Centre of Hill Bioresources and Biotechnology, CSK Himachal Pradesh Krishi Vishvavidyalaya, Palampur-176062, India.

Accepted for publication 9 November 2004.

DOI: 10.1094/PD-89-0385

This article is in the public domain and not copyrightable. It may be freely reprinted with customary crediting of the source. The American Phytopathological Society, 2005. and hence is difficult to manage by the use of chemicals. Pathogenic and genetic variability in the pathogen was characterized using differential lines and DNA markers $(6,19,23)$. Efforts were also made to develop race-specific DNA-based markers for certain races $(2,11,12)$. The pathogen has eight races $(6,9,18)$. Races $1 \mathrm{~A}, 2,3$, and 4 have been reported from India, and races $0,1 \mathrm{~A}, 1 \mathrm{~B} / \mathrm{C}, 5$, and 6 , from the United States and Spain.

Cultivar specialization (race) of $F$. oxysporum f. sp. ciceris was first reported in India (6). Subsequently, resistance to wilt in chickpea has been shown to be racespecific and governed by major resistance genes $(20,27,30)$. Resistance to races 0 , $1 \mathrm{~A}, 2$, and 4 is either digenic or trigenic, whereas resistance to races 3 and 5 is monogenic $(20,25)$. Resistance to race 0 is conferred by one gene in the germ plasm line JG-62 and by another gene in CA2139 (19). Resistance to race 4 is recessive, monogenic in WR-315, while it is recessive, digenic in Surutato-77 $(27,28)$. Reaction of $F_{2}$ and $F_{3}$ populations derived from a cross of WR-315 (resistant) and C-104 (susceptible) showed the digenic ( $a$ and $b$ ) nature of resistance in WR-315 to race 2 (14). Both these genes in recessive form $(a a b b)$ conferred resistance in WR-315, whereas $A A B B$ led to susceptibility in C104. Other crosses revealed involvement of a third gene named $C$ for resistance to race $2(4,14)$. The genetics of the resistance to race 5 in WR-315 and C-104 is still unknown, and previous reports about the genetics of resistance to other races are inconsistent.

Some susceptible chickpea lines exhibit a phenomenon termed late wilting, which is characterized by an extended latent period (the time between inoculation and first appearance of visual wilt symptoms), followed by a normal rate of disease development after onset of the visual symptoms (29). While studying genetics of resistance to race $1 \mathrm{~A}$, late wilting was found to be governed by any one of the three genes, $h_{1}$, $h_{2}$, and $H_{3}$, associated with race $1 \mathrm{~A}$ resistance, whereas any two of these three genes conferred resistance (no wilt) $(21,29,30)$. Late wilting was also detected in some lines susceptible to race 2 . Of the three independent genes ( $a, b$, and $C)$ found to govern resistance to race 2 , a combination of any two conferred resistance, whereas any one of these genes led to late wilting $(4,14)$.

Identification of races of $F$. oxysporum $\mathrm{f}$. sp. ciceris has been complicated by the availability of several different sets of differentials, and some of the differentiation is based on intermediate reactions. Differential lines in the previously reported sets ranged from as few as eight to as many as $22(3,6,10,26)$. In all those reported differential sets, differentiation between races 2 and 3 is not precise and is based on an intermediate or a moderate reaction of some differential lines. For example, Chaffa is intermediate in reaction to race 3 and resistant to race 2 (26). Since resistance to wilt in chickpea is race-specific and governed by major resistance genes, there is a need to develop an improved differential set for chickpea wilt to reduce ambiguity in race determination. It would also be desirable to reduce the number of lines in proportion to the number of races, and the lines should have clear and consistent disease phenotype (e.g., clear resistant or susceptible reactions). The race identification would be more precise if all lines of the set wilt early, preferably at the same time, and do not have late wilting. Another factor that has complicated the race deter- 
mination process is inconsistent criteria in defining resistance and susceptibility. Disease scoring scales used to phenotype resistance and susceptibility for race identification have varied considerably among different studies (Table 1). Lines scored as resistant in one study might have been categorized as medium-moderately susceptible-intermediate in other studies, and lines scored as susceptible in one study may be considered moderate in another study. Different terminologies, such as medium, moderately susceptible, and intermediate, have further complicated the process of race identification.

We had two main objectives in this study: (i) to elucidate genetics of resistance in WR-315 to race 5 and to confirm the genetics of resistance in WR-315 to races $1 \mathrm{~A}, 2,3$, and 4 of $F$. oxysporum f. sp. ciceris, and (ii) to develop a concise set of differential lines to identify races of $F$. oxysporum f. sp. ciceris with greater precision. In addition, we report a phenomenon of slow wilting that is different from previously reported late wilting.

\section{MATERIALS AND METHODS}

Chickpea genotypes, fungal strains, and inoculum preparation. Three groups of chickpea genotypes were used in this study. The first group was comprised of 27 germ plasm lines of $C$. arietinum and two germ plasm lines of $C$. reticulatum, including those that were used previously as differentials for races of $F$. oxysporum f.

Table 1. Disease scoring scales used in previous studies to phenotype chickpea differential lines for resistance and susceptibility to races of Fusarium oxysporum f. sp. ciceris

\begin{tabular}{lccc}
\hline & \multicolumn{3}{c}{ Disease scoring scale (\% wilt incidence) } \\
\cline { 2 - 4 } Reference & Resistant & Moderately susceptible & Susceptible \\
\hline Haware and Nene (6) & $0-20$ & $21-50$ & $>50$ \\
Phillips (18) & $0-20$ & $21-50$ & $>50$ \\
Jimenez-Diaz et al. (10) & $0-33$ & $34-66$ & $67-100$ \\
El-Hadi (3) & $1-10$ & $11-50^{\mathrm{a}}$ & $51-100$ \\
Tullu (26) & $1-10$ & $11-90^{\mathrm{b}}$ & $91-100$ \\
\hline
\end{tabular}

${ }^{a}$ Disease reaction: medium.

${ }^{\mathrm{b}}$ Disease reaction: intermediate.

sp. ciceris (Table 2). These germ plasm lines were obtained from the USDA Western Regional Plant Introduction Station, Pullman, WA. The second group was comprised of $100 \mathrm{~F}_{7}$ recombinant inbred lines (RILs) from a cross between WR-315 and C-104. WR-315 is resistant to races $1 \mathrm{~A}, 2$, 3, 4, and 5 of $F$. oxysporum f. sp. ciceris, whereas $\mathrm{C}-104$ is susceptible to the five races $(14,16,20,28)$. The third group of chickpea genotypes was comprised of 26 $\mathrm{F}_{2}$ plants from a cross of the same two parents, WR-315 and C-104. The second and third groups of chickpea genotypes were generated by and maintained at the USDA ARS Grain Legume Genetics and Physiology Research Unit at Pullman, WA.

Isolates of five races of $F$. oxysporum $\mathrm{f}$. sp. ciceris were used in this study. Races 1A, 2, 3, and 4 were obtained from International Crop Research Institute for SemiArid Tropics (ICRISAT), Patancheru, India, and race 5 isolate was provided by Walter Kaiser, Western Regional Plant Introduction Station, Pullman, WA, who obtained it from Antonio Traperas and Rafael Jimenez Diaz, Departmento de Protection de Cultivos, Instituto de Agricultura Sostenible, CSIC, Apartado, Cordoba, Spain. Races 0 and 6 were not included because the strains in our collection

Table 2. List of chickpea genotypes used in the present study and their reactions to five races of Fusarium oxysporum f. sp. ciceris

\begin{tabular}{|c|c|c|c|c|c|c|c|c|}
\hline \multirow[b]{2}{*}{ Name } & \multirow[b]{2}{*}{ Accession no. } & \multirow[b]{2}{*}{ Alternative identifiers/pedigree } & \multirow{2}{*}{$\begin{array}{l}\text { Country } \\
\text { of origin }\end{array}$} & \multicolumn{5}{|c|}{ Race $^{\mathbf{a}}$} \\
\hline & & & & $\mathbf{1 A}$ & 2 & 3 & 4 & 5 \\
\hline \multicolumn{9}{|c|}{ Differentiation based on resistant or susceptible reactions } \\
\hline ICC 7537 & W6 17441 & $\ldots$ & Ethiopia & $\mathrm{R}$ & $\mathrm{R}$ & $\mathrm{R}$ & $\mathrm{S}$ & $\mathrm{R}$ \\
\hline Sanford & 598078 & FLIP85-58 $\times$ Surutato-77 & USA & $\mathrm{R}$ & $\mathrm{S}$ & $\mathrm{S}$ & $\mathrm{S}$ & $\mathrm{S}$ \\
\hline White Spanish & 503005 & $\ldots$ & USA & $\mathrm{R}$ & $\mathrm{S}$ & $\mathrm{S}$ & $\mathrm{S}$ & $\mathrm{S}$ \\
\hline Chaffa & 374099 & $\ldots$ & Iran & $\mathrm{S}$ & $\mathrm{R}$ & I & $\mathrm{S}$ & $\mathrm{S}$ \\
\hline DZ 10-4 & W6 17740 & ICC 7534, ILC 2538 & Ethiopia & $\mathrm{R}$ & $\mathrm{R}$ & $\mathrm{R}$ & $\mathrm{S}$ & $\mathrm{S}$ \\
\hline Dwelley & 598079 & FLIP85-58 $\times$ Surutato-77 & USA & $\mathrm{R}$ & $\mathrm{R}$ & $\mathrm{S}$ & $-^{\mathrm{b}}$ & - \\
\hline PI359075(1) & 359075 & RPIP 12-069-00103 & India & $\mathrm{S}$ & $\mathrm{R}$ & $\mathrm{R}$ & - & - \\
\hline ICCV-4 & 572506 & $\ldots$ & India & $\mathrm{R}$ & I & $\mathrm{I}$ & $\mathrm{S}$ & $\mathrm{S}$ \\
\hline \multicolumn{9}{|c|}{ Differentiation based on intermediate reactions } \\
\hline JG-74 & 439833 & ICC 6098 & India & $\mathrm{R}$ & $\mathrm{R}$ & $\mathrm{R}$ & $\mathrm{I}$ & I \\
\hline Annigeri & 572500 & $\ldots$ & India & $\mathrm{R}$ & $\mathrm{R}$ & $\mathrm{R}$ & $\mathrm{R}$ & I \\
\hline ICCV-2 & 557450 & $\begin{array}{l}\mathrm{F} 3(\mathrm{~K} 850 \times \mathrm{GW} 5 / 7) \times \mathrm{P}-458) \times \mathrm{F} 3(\mathrm{~L}-550 \times \\
\text { Guamuchil) }-2\end{array}$ & India & $\mathrm{R}$ & $\mathrm{R}$ & I & $\mathrm{R}$ & I \\
\hline $\mathrm{K}-850$ & 426616 & & Pakistan & $\mathrm{R}$ & $\mathrm{R}$ & $\mathrm{R}$ & I & I \\
\hline ICC-7520 & 451623 & 12-071/10054, W6 9501 & Iran & $\mathrm{R}$ & $\mathrm{R}$ & I & $\mathrm{R}$ & $\mathrm{R}$ \\
\hline CPS-1 & 439856 & ICC 10130 & India & $\mathrm{R}$ & $\mathrm{R}$ & $\mathrm{R}$ & I & I \\
\hline FLIP84-92C(2) & 614731 & PI 564774(ILC-72) × W6 22580(ILC-215) & USA & $\mathrm{S}$ & I & $\mathrm{S}$ & $\mathrm{S}$ & $\mathrm{S}$ \\
\hline FLIP84-92C(3) & 614731 & PI 564774(ILC-72) × W6 22580(ILC-215) & USA & S & I & $\mathrm{S}$ & $\mathrm{S}$ & $\mathrm{S}$ \\
\hline \multicolumn{9}{|l|}{ No differentiation } \\
\hline PI359075(2) & 359075 & RPIP 12-069-00103 & India & $\mathrm{S}$ & $\mathrm{S}$ & $\mathrm{S}$ & - & _- \\
\hline ICC 6426 & 359085 & RPIP 12-069-00117, NEC-406 & India & $\mathrm{R}$ & $\mathrm{R}$ & $\mathrm{R}$ & - & - \\
\hline C. reticulatum & 599072 & $\ldots$ & Turkey & S & $\mathrm{S}$ & $\mathrm{S}$ & $\mathrm{S}$ & $S$ \\
\hline JG-62 & 439821 & ICC 4951 & India & $\mathrm{S}$ & $\mathrm{S}$ & $\mathrm{S}$ & $\mathrm{S}$ & $\mathrm{S}$ \\
\hline C-104 & 315786 & $\begin{array}{l}\text { ILC-245, ICC 6331, ICC 8231, NEC-246, } \\
\text { NEC-2393 }\end{array}$ & India & $\mathrm{S}$ & $\mathrm{S}$ & $\mathrm{S}$ & $\mathrm{S}$ & $\mathrm{S}$ \\
\hline L-550 & 426163 & $\mathrm{C} 104 \times \mathrm{NP} 12$ & India & $\mathrm{S}$ & $\mathrm{S}$ & $\mathrm{S}$ & $\mathrm{S}$ & $\mathrm{S}$ \\
\hline C. reticulatum & 489777 & ICCW 45, ILWC 36, ATC 42236 & Turkey & $\mathrm{S}$ & $\mathrm{S}$ & $\mathrm{S}$ & $\mathrm{S}$ & $\mathrm{S}$ \\
\hline P-2245 & 572531 & PV-13 & Spain & $\mathrm{S}$ & $\mathrm{S}$ & $\mathrm{S}$ & $\mathrm{S}$ & $\mathrm{S}$ \\
\hline BG-212 & 439861 & ICC 11088 & India & $\mathrm{R}$ & $\mathrm{R}$ & $\mathrm{R}$ & $\mathrm{R}$ & $\mathrm{R}$ \\
\hline WR-315 & 439850 & ICC 8933 & India & $\mathrm{R}$ & $\mathrm{R}$ & $\mathrm{R}$ & $\mathrm{R}$ & $\mathrm{R}$ \\
\hline Surutato-77 & W6 17605 & $(\mathrm{~L}-1186 \times$ Macarena $) \times$ Macarena & Mexico & $\mathrm{R}$ & - & $\mathrm{R}$ & $\mathrm{R}$ & $\mathrm{R}$ \\
\hline ICC 4958 & 439824 & JGC-2, GW5/7 & India & $\mathrm{R}$ & $\mathrm{R}$ & $\mathrm{R}$ & $\mathrm{R}$ & $\mathrm{R}$ \\
\hline Blanco Lechoso & 632396 & CA 2969 & Spain & $\mathrm{S}$ & $\mathrm{S}$ & $\mathrm{S}$ & - & - \\
\hline
\end{tabular}

a $\mathrm{R}=$ resistant ( 0 to $10 \%$ wilt), $\mathrm{I}=$ intermediate (11 to $89 \%$ wilt), $\mathrm{S}=$ susceptible (90 to $100 \%$ wilt).

${ }^{\mathrm{b}}$ Not tested. 
had lost pathogenicity or they were not available. Isolates of fungal strains were maintained on cellulose filter papers at $-20^{\circ} \mathrm{C}$, revived on liquid V8 juice agar medium $(150 \mathrm{ml}$ of $\mathrm{V} 8$ juice, $3 \mathrm{~g}$ of calcium carbonate, and $16 \mathrm{~g}$ of agar per liter of the medium) plates, and multiplied on liquid V8 juice medium. Single spore isolates of each strain were established and tested for pathogenicity on a highly susceptible cultivar P-2245 (20). Each isolate was tested on a set of chickpea differential lines (26) to confirm their race identity at the beginning and was used throughout this study. In addition, molecular differences among strains of races 2, 3, and 4 were confirmed using random amplified polymorphic DNA (RAPD) with three primers, OPI-18, OPF-6, and OPF-10, as described previously (11).

Inocula of the five races were prepared from 21-day-old cultures grown in liquid $\mathrm{V} 8$ juice medium at $25^{\circ} \mathrm{C}$ at $100 \mathrm{rpm}$ under continuous cool fluorescent light. The mycelium of the cultures was removed by passing through four layers of cheesecloth, and the concentration of spores present in the liquid medium was adjusted to $1 \times 10^{6}$ per $\mathrm{ml}$ using a hemacytometer.

Pathogenicity assays. Chickpea seeds were pregerminated in moist paper towels in petri dishes for 3 days, and then planted into perlite. Plants were uprooted at the three- to four-leaf-stage. After the lower one-fifth of the roots were trimmed with sterile scissors, the plants were dipped in inoculum for $5 \mathrm{~min}$ and transplanted into a 1:1 mix of potting soil and perlite in trays $(50 \times 35 \times 10.6 \mathrm{~cm})$. Four chickpea genotypes (10 plants each in a row) were randomly assigned to a tray. Each row of 10 plants was one replication. Uninoculated control plants were treated the same way except that their roots were dipped in sterile water for $5 \mathrm{~min}$. The inoculated plants were grown under growth room conditions with a temperature regime of 26 and $22^{\circ} \mathrm{C}$ (12 h:12 h) and 16-h photoperiod under fluorescent light. The plants were watered daily and supplied with nutrient solution $\left(10 \% \mathrm{~N}, 10 \% \quad \mathrm{P}_{2} \mathrm{O}_{5}, 10 \% \quad \mathrm{~K}_{2} \mathrm{O}, 0.025 \%\right.$ $\mathrm{Mg}, 0.0034 \% \mathrm{~B}, 0.0018 \% \mathrm{Cu}$ (chelated), $0.025 \% \mathrm{Fe}$ (chelated), $0.0125 \% \mathrm{Mn}$ (chelated), $0.00045 \% \mathrm{Mo}$, and $0.00125 \% \mathrm{Zn}$ ) once a week for the first 2 weeks after transfer and twice a week thereafter. Disease incidence (percent wilting) was recorded weekly from week 2 to week 8 after inoculation.

The 29 germ plasm lines and the 100 RILs were tested for reaction to each of the five races with three replications in a completely randomized design. Due to space limitations, the 100 RILs were tested in successive batches, and several lines were included in each batch to facilitate comparing results between batches. The entire experiment was performed twice. The lines that gave differential reaction to any of the five races were re-evaluated one more time in one batch using the same procedure.

The genetic mechanism of resistance to race 2 in WR-315 was evaluated using a $F_{2}$ population from the cross $\mathrm{W}-315 \times \mathrm{C}-104$. Twenty-six $F_{2}$ seeds were obtained from one $F_{1}$ seed. The $F_{2}$ plants were inoculated with inoculum of race 2 as described above. Data on wilt incidence were collected 42 days after inoculation.

Two experiments were conducted to investigate slow wilting. In the first experiment, plants of FLIP84-92C(3), PI599072, WR-315, and C-104 were compared for their reactions to race 2 . The experiment was performed in trays with three replications (10 plants per replication) as described above. In the second experiment, C-104 and FLIP 84-92C plants were inoculated with each of the five races. The inoculated plants were grown in flats with 10 plants per replication and three replications per treatment as described above. When the second experiment was repeated, only FLIP 84-92C was used, and the inoculated plants were grown in plastic pots with three replications for a total of 15 plants (three pots each with five plants per replication). Disease incidence was recorded starting 2 weeks after inoculation at weekly intervals for 8 weeks.

Completely randomized designs were used for all experiments in this study. The disease incidence data were converted to categorical data in the following way: 0 to $10 \%$ wilting $=$ resistance, 11 to $89 \%$ wilting $=$ intermediate, $>90 \%$ wilting $=$ susceptible. Chi-square analysis was used to test the goodness of fit for one, two, or three genes governing resistance to individual races when appropriate.

\section{RESULTS}

Wilt reaction and genetics of resistance. Of the 29 germ plasm lines evaluated for wilt reaction to five races, $16 C$. arietinum lines showed differential reaction. Eight (ICC 7537, Sanford, Chaffa, DZ10-4, White Spanish, PI359075(1), ICCV 4, and Dwelley) of these 16 lines differentiated at least one race from others based on resistant or susceptible reactions, whereas the remaining eight lines differentiated the races on the basis of an intermediate reaction (Table 2). Both lines of $C$. reticulatum (PI489777, PI599072) were susceptible to all five races.

Among the 100 RILs, 44 were susceptible to all five races, 35 were resistant to all five races, and the remaining 21 showed differential responses to the five races. Among the 21 RILs demonstrating differential responses to pathogen races, only 10 (1-8, 1-17, 1-36, 1-37, 1-53, 1-70, 1-78, 1$81,1-91$, and 1-94) could delineate at least one race from others with resistant or susceptible reactions, and the other 11 differentiated the races by intermediate reactions (Table 3). Chi-square analysis of the RILs that had either resistant or susceptible reactions showed a goodness of fit to a 1:1 ratio (resistant:susceptible), indicating that WR-315 possesses monogenic resistance to each of the five races (Table 4).

Twenty-six $\mathrm{F}_{2}$ plants were inoculated with race 2 , out of which 21 wilted after 6 weeks and 5 survived. These data fit well into a 3:1 (susceptible:resistant) ratio with a $\chi^{2}$ value of 0.46 and probability value of 0.50 , indicating that resistance in WR-315 to race 2 is governed by a single recessive gene.

Slow wilting. Chickpea line FLIP8492C(3) was compared with C-104, PI

Table 3. List of chickpea recombinant inbred lines (CRIL) derived from a cross of WR-315 and C-104 that showed differential reactions to five races of Fusarium oxysporum f. sp. ciceris

\begin{tabular}{|c|c|c|c|c|c|}
\hline \multirow[b]{2}{*}{ CRIL } & \multicolumn{5}{|c|}{ Race $^{\mathbf{a}}$} \\
\hline & $\mathbf{1 A}$ & 2 & 3 & 4 & 5 \\
\hline \multicolumn{6}{|c|}{ Differentiation based on resistant or susceptible reactions } \\
\hline CRIL-1-8 & $\mathrm{R}$ & $\mathrm{S}$ & $\mathrm{R}$ & $\mathrm{S}$ & I \\
\hline CRIL-1-17 & $\mathrm{R}$ & $\mathrm{R}$ & $\mathrm{R}$ & $\mathrm{S}$ & $\mathrm{R}$ \\
\hline CRIL-1-36 & I & $\mathrm{S}$ & $\mathrm{S}$ & $\mathrm{S}$ & $\mathrm{R}$ \\
\hline CRIL-1-37 & $\mathrm{S}$ & $\mathrm{S}$ & $\mathrm{S}$ & $\mathrm{S}$ & $\mathrm{R}$ \\
\hline CRIL-1-53 & $\mathrm{S}$ & $\mathrm{R}$ & $\mathrm{R}$ & $\mathrm{R}$ & $\mathrm{R}$ \\
\hline CRIL-1-70 & $\mathrm{R}$ & $\mathrm{S}$ & $\mathrm{R}$ & $\mathrm{R}$ & $\mathrm{R}$ \\
\hline CRIL-1-78 & $\mathrm{S}$ & $\mathrm{R}$ & $\mathrm{R}$ & $\mathrm{S}$ & I \\
\hline CRIL-1-81 & $\mathrm{R}$ & $\mathrm{R}$ & I & $\mathrm{S}$ & $\mathrm{R}$ \\
\hline CRIL-1-91 & $\mathrm{S}$ & $\mathrm{S}$ & $\mathrm{S}$ & $\mathrm{S}$ & $\mathrm{R}$ \\
\hline CRIL-1-94 & $\mathrm{R}$ & S & $\mathrm{R}$ & I & I \\
\hline \multicolumn{6}{|c|}{ Differentiation based on intermediate reactions } \\
\hline CRIL-1-7 & $\mathrm{R}$ & I & I & $\mathrm{R}$ & $\mathrm{R}$ \\
\hline CRIL-1-18 & $\mathrm{S}$ & $\mathrm{S}$ & $\mathrm{S}$ & $\mathrm{S}$ & I \\
\hline CRIL-1-20 & $\mathrm{R}$ & I & $\mathrm{R}$ & $\mathrm{R}$ & $\mathrm{R}$ \\
\hline CRIL-1-23 & $\mathrm{R}$ & $\mathrm{R}$ & $\mathrm{R}$ & I & $\mathrm{R}$ \\
\hline CRIL-1-26 & $\mathrm{R}$ & I & I & I & $\mathrm{R}$ \\
\hline CRIL-1-32 & I & $\mathrm{S}$ & $\mathrm{S}$ & $\mathrm{S}$ & $\mathrm{S}$ \\
\hline CRIL-1-34 & $\mathrm{S}$ & $\mathrm{S}$ & $\mathrm{S}$ & $\mathrm{S}$ & I \\
\hline CRIL-1-35 & $\mathrm{S}$ & $\mathrm{S}$ & $\mathrm{S}$ & $S$ & I \\
\hline CRIL-1-83 & $\mathrm{R}$ & I & $\mathrm{R}$ & $\mathrm{R}$ & $\mathrm{R}$ \\
\hline CRIL-1-93 & $\mathrm{S}$ & $S$ & I & $S$ & I \\
\hline CRIL-1-95 & $\mathrm{S}$ & $\mathrm{S}$ & I & $\mathrm{S}$ & $\mathrm{S}$ \\
\hline
\end{tabular}

${ }^{a} \mathrm{R}=$ resistant ( 0 to $10 \%$ wilt), $\mathrm{I}=$ intermediate ( 11 to $89 \%$ wilt), $\mathrm{S}=$ susceptible ( 90 to $100 \%$ wilt). 
599072, and WR-315 for their reactions to race 2. Four weeks after inoculation, all plants of PI599072 and C-104 wilted and died, and WR-315 survived and showed no wilt. Wilt incidence of FLIP84-92C(3) was only $13.3 \% 4$ weeks after inoculation, indicating that this line possesses some degree of resistance to race 2 . In the second experiment, FLIP84-92C(3) and C104 were inoculated with five races of the pathogen. C-104 had 30 and 100\% wilt incidence 2 and 3 weeks, respectively, after inoculation with race 2 . In contrast, FLIP84-92C(3) showed 0, 2.7, and 15\% wilt incidence 2,3 , and 4 weeks, respectively, after inoculation with the same race (Fig. 1). Wilt incidence continued to increase and was $31.1,60.5$, and $84.4 \%$ at 5 , 6 , and 7 weeks after inoculation, respectively. Terminal disease incidence was $86.6 \%$ after 8 weeks of inoculation and was stable thereafter. This line, however, did not show any resistance to races $1 \mathrm{~A}, 3$, 4 , and 5 , as all plants wilted within 4 to 5 weeks after inoculation (Fig. 1). Figure 2 contrasts the susceptible reaction of FLIP84-92C(3) to race 1A with its intermediate reaction to race 2 at 8 weeks after inoculation. Essentially the same data were obtained when the experiment was repeated with only FLIP84-92C(3). The slow progress of wilt by race 2 on FLIP84-92C(3) after appearance of first wilt symptoms and survival of $13.4 \%$ of plants even after prolonged incubation indicated that this phenomenon was different from the late wilting reported earlier (29). In addition to slow progress of the disease, onset of visual wilt symptoms on FLIP84-92C(3) was also 1 week later than on C-104.

Slow wilting was also observed in some $\mathrm{F}_{7}$ RILs in reaction to races 2 and 3. Fiftyfive and 40 RILs showed 100 and $0 \%$ wilt incidence, respectively, to race 2 . The remaining five RILs were intermediate, and increase in wilt incidence over extended time was observed only in two RILs (CRIL-1-7 and CRIL-1-83) (Fig. 3A). First appearance of disease on CRIL-1-7 and CRIL-1-83 was recorded during the third and fourth weeks, and terminal mean disease incidence was 60.7 and $63.2 \%$, respectively, 7 weeks after inoculation. Similarly, five RILs were intermediate in reaction to race 3 and three (CRIL-1-7, CRIL-1-26, and CRIL-1-93) of these five RILs were slow wilting (Fig. 3B). The onset of wilt symptoms on these RILs varied between 3 and 4 weeks; however, the progress of disease was slow thereafter and terminal disease incidence ranged from 26.7 to $63.3 \%$. Slow wilting to races $1 \mathrm{~A}, 4$, and 5 was not observed in any of the RILs or any of the other chickpea genotypes used in this study.

Differential set for race identification. Eight lines as a set of differentials were selected from the chickpea genotypes used in this study based on the clearest and most precise differential reactions (Table 5). In most cases, the selected susceptible lines wilted within 4 weeks of inoculation, whereas the resistant lines remained healthy even 8 weeks after inoculation. The selected lines could differentiate the five races based on no wilt and $100 \%$ wilt incidence with two exceptions, JG62 for race $2(94.3 \%$ wilting) and Sanford for race 5 ( $95.0 \%$ wilt incidence). Reactions of CRIL-1-94 to races 4 and 5 and that of CRIL-1-36 to race 1A were intermediate. There are differentials in this set that can differentiate the five races based on unambiguous reactions. For instance, CRIL-194 can be used to differentiate race 2 from race 3 (Fig. 4) because it is susceptible to race $2(100 \%$ wilt $)$ and resistant to race 3 (no wilt).

\section{DISCUSSION}

Through evaluating $100 \mathrm{~F}_{7}$ RILs from a cross between WR-315 and C-104, we have determined for the first time that the resistance in WR-315 to race 5 of $F$. $o x$ ysporum f. sp. ciceris is monogenic. We also confirmed previous reports $(13,16,20,28)$ on the monogenic nature of resistance in WR-315 to races $1 \mathrm{~A}, 3$, and 4. Since we used RILs, the dominant or recessive nature of resistance is not known. Previously, Tekeoglu et al. (25) showed that resistance in ICC4958 to race 5 is also monogenic. Our results from evaluating both RILs and $F_{2}$ populations showed that the resistance in WR-315 to race 2 is conferred by a single recessive gene, which is contrary to previous reports $(4,14)$. The two previous studies on resistance in WR315 to race 2 were not in agreement with each other either. Kumar (14) concluded that the resistance was trigenic, whereas Gumber et al. (4) proposed a two-gene hypothesis. In the current study, both parental lines reacted to race 2 the same way as in previous studies $(4,14)$. C-104 was susceptible to race 2 (not late wilt) and WR-315 was resistant. The number of

Table 4. Reaction of $\mathrm{F}_{7}$ recombinant inbred lines derived from a cross of WR-315 and C-104 to five races of Fusarium oxysporum f. sp. ciceris

\begin{tabular}{lcccc}
\hline Race & Resistant $^{\mathbf{a}}$ & Susceptible $^{\mathbf{a}}$ & $\chi^{\mathbf{2}}$ & Probability \\
\hline 1A & 45 & 53 & 0.65 & 0.44 \\
2 & 40 & 55 & 2.36 & 0.13 \\
3 & 44 & 51 & 0.52 & 0.48 \\
4 & 40 & 57 & 2.98 & 0.08 \\
5 & 47 & 46 & 0.04 & 0.85 \\
\hline
\end{tabular}

${ }^{\text {a }}$ Resistant $=0$ to $10 \%$ wilt incidence, susceptible $=90$ to $100 \%$ wilt incidence.
RILs that showed $100 \%$ wilt incidence to race 2 was 55 at 4 weeks after inoculation and remained the same even 8 weeks after inoculation. We did observe two RILs that are slow wilting in reaction to race 2 , whereas three other RILs were intermediate in reaction. Furthermore, our results from the $F_{2}$ population also supported the one gene theory obtained with RILs for reaction to race 2 . The cause of the discrepancies among the three studies is unknown. It could be due to different strains of race 2 being used, or due to environmental conditions. While studying progenies of $\mathrm{F}_{3}$ plants developed from a cross between WR-315 and C-104, Kumar (14) observed an excess of susceptible progenies compared with those expected for resistance governed by two genes, and speculated that this bias toward susceptibility was due to the failure of some resistant plants to occur in some progenies.

Slow wilting in chickpea is a phenomenon not previously reported. Progress of wilt on FLIP84-92C(3) was significantly slower after initial onset of symptoms by race 2 than by other races (Fig. 1). More than $10 \%$ of the inoculated plants remained healthy even at 8 weeks after inoculation with race 2 , whereas plants inoculated with the other four races completely wilted by week 5 . Thus, slow wilt in FLIP84-92C(3) appeared to be race-specific. The slow wilting reported here is clearly different from late wilting. Late wilting refers to susceptible lines showing a prolonged latent period (from inoculation to first appearance of wilt symptom). Once symptoms start showing, disease progress is rapid and disease incidence approaches $100 \%$. With slow wilting, however, the first signs of disease appeared at about the same time as in other susceptible lines, but disease incidence increased slowly over time. The final rating of disease incidence usually gives an intermediate reaction. Therefore, slow wilting differs from late wilting in three aspects: latent period, disease progress rate, and final disease severity. Late wilting

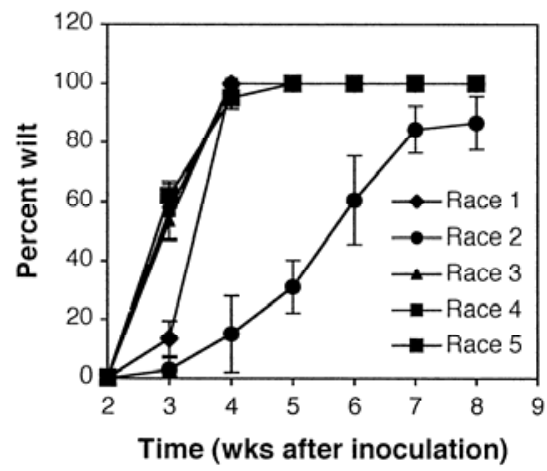

Fig. 1. Progress of wilt on chickpea line FLIP84-92C(3) after inoculation with races 1A, 2, 3, 4, and 5 of Fusarium oxysporum f. sp. ciceris. Each data point represents the mean \pm standard error $(n=3)$. 
is considered of importance in chickpea breeding, as it is expected to delay disease development during the growing season $(14,29)$

The phenomenon of slow wilting in chickpea is similar to slow mildewing reported in pea and Medicago $(1,32)$ and slow rusting in wheat, leak, faba bean, and oat $(7,15,22,24)$. Slow mildewing and slow rusting have been characterized by the low rate of disease progress after initiation of symptoms in some cultivars compared to susceptible ones. Thus, the slow rate of disease progress over time observed in our studies is termed slow wilting. To our knowledge, this is the first report of slow wilting of Fusarium wilt in chickpea. Slow wilting might be useful in chickpea breeding for controlling Fusarium wilt to reduce chances of evolution of new races. The phenomenon of late wilting in chickpea is controlled by single genes $(21,30)$, but the genetics of slow wilting is unknown. One possible explanation could be the presence of some minor genes that might act in an additive manner and lead to slow wilting. However, this does not appear to explain the race-specific nature of slow wilting observed here. In addition to FLIP84$92 \mathrm{C}(3)$, a few of the RILs used in this study also showed an intermediate reaction, and some are slow wilting (Fig. 3). Although there is about $2.1 \%$ heterozygosity in $\mathrm{F}_{7}$ RILs, the slow wilting occurred only to races 2 and 3 , and none of the 100 RILs reacted in a slow wilting manner to the other races. The germ plasm line FLIP84-92C(3) and the few slow wilting
RILs (Fig. 3) provide genetic materials for future studies to elucidate the genetics of slow wilting.

Resistance in chickpea to races of Fusarium wilt is inherited as major genes and shown as vertical resistance. We feel that the most appropriate classification scheme for phenotypic reactions is resistant (0 to $10 \%$ wilt incidence), intermediate (11 to $89 \%$ wilt incidence), and susceptible (90 to $100 \%$ wilt incidence). The reported late wilting chickpea genotypes also show $100 \%$ wilt incidence with delayed onset of symptoms $(4,14,21,29,30)$ and should also fit well into the proposed classification. Slow wilting reactions will fall into the intermediate category. A margin of $10 \%$ has been kept for variability due to environmental variation and experimental errors.

Seventy-nine of the 100 RILs showed the phenotype of either parent with respect to resistance to the five races (44 susceptible and 35 resistant to all five races). Only 21 RILs showed recombinant phenotypes in reaction to the five races, with 10 delineating races based on resistant or susceptible reactions. Thus, genes for resistance to the five races might be linked. Linkage between resistance genes and DNA markers was established, and the five genes were found to be on one linkage group (K. D. Sharma, W. Chen, and F. J. Muehlbauer, unpublished).

The selected differential set of eight lines is smaller than a set of 22 used previously (26). To facilitate precise and reproducible race identification, we selected lines that wilted early (within 4 weeks of

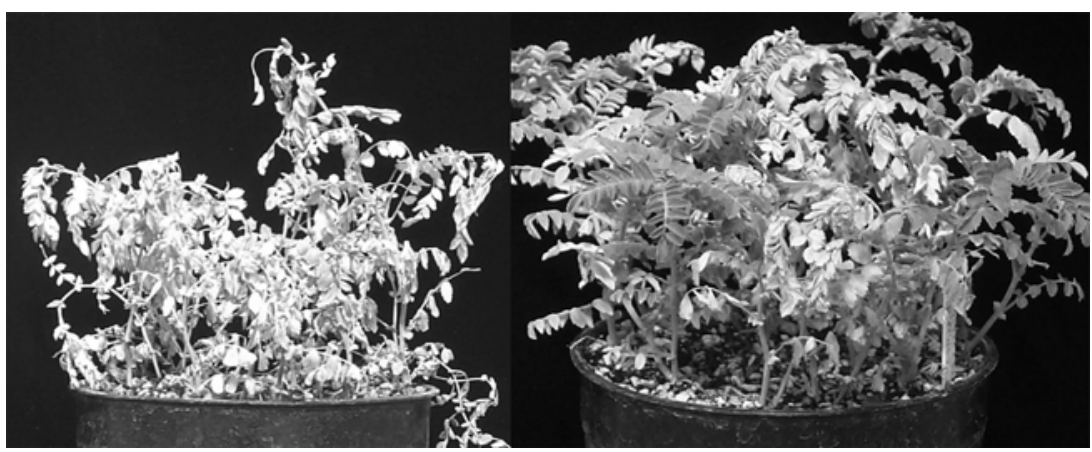

Fig. 2. Chickpea line FLIP-84-92C(3) inoculated with race 1A (left, susceptible reaction) and race 2 (right, intermediate reaction) of Fusarium oxysporum f. sp. ciceris 8 weeks after inoculation.

Table 5. List of selected chickpea differentials and their reactions to five races of Fusarium oxysporum f. sp. ciceris

\begin{tabular}{|c|c|c|c|c|c|c|}
\hline $\begin{array}{l}\text { Germ plasm } \\
\text { accession }\end{array}$ & $\begin{array}{l}\text { Differential } \\
\text { line }\end{array}$ & Race $1 A^{\mathrm{a}}$ & Race 2 & Race 3 & Race 4 & Race 5 \\
\hline W6-24867 & $\mathrm{JG}-62^{\mathrm{b}}$ & $S(100.0)$ & S (94.3) & $S(100.0)$ & $S(100.0)$ & $\mathrm{S}(100.0)$ \\
\hline W6-24868 & P-2245 b & S (100.0) & $\mathrm{S}(100.0)$ & $S(100.0)$ & $S(100.0)$ & $\mathrm{S}(100.0)$ \\
\hline W6-24869 & SANFORD & $\mathrm{R}(0)$ & $S(100.0)$ & $S(100.0)$ & $S(100.0)$ & $\mathrm{S}(95.0)$ \\
\hline W6-24870 & CRIL-1-53 & S (100.0) & $\mathrm{R}(0)$ & $\mathrm{R}(0)$ & $\mathrm{R}(0)$ & $\mathrm{R}(0)$ \\
\hline W6-24871 & CRIL-1-94 & $\mathrm{R}(0)$ & $S(100.0)$ & $\mathrm{R}(0)$ & I (36.4) & I (30.0) \\
\hline W6-24872 & CRIL-1-17 & $\mathrm{R}(0)$ & $\mathrm{R}(0)$ & $\mathrm{R}(0)$ & $S(100.0)$ & $\mathrm{R}(0)$ \\
\hline W6-24874 & CRIL-1-36 & I (33.3) & S (100.0) & $S(100.0)$ & $S(100.0)$ & $\mathrm{R}(0)$ \\
\hline W6-24876 & WR-315 & $\mathrm{R}(0)$ & $\mathrm{R}(0)$ & $\mathrm{R}(0)$ & $\mathrm{R}(0)$ & $\mathrm{R}(0)$ \\
\hline
\end{tabular}

a $\mathrm{S}=$ susceptible, $\mathrm{R}=$ resistant, $\mathrm{I}=$ intermediate, disease incidence (\%) in parentheses.

b JG-62 and P-2245 are resistant and susceptible, respectively, to race $0(19,26)$. inoculation) and showed extreme phenotype ( 0 or $100 \%$ wilt incidence) to different races. The lines with intermediate reaction were avoided with the exception of CRIL-1-94 and CRIL-1-36. CRIL-1-94 was one of the best lines for differentiation between race $2(100 \%$ wilt) and race $3(0 \%$ wilt) and CRIL-1-36 for differentiation between race 4 (100\% wilt) and race $5(0 \%$ wilt). Although not tested in this study, JG62 is resistant to race $0(19,26)$ and is retained in the set to differentiate race 0 from the other races. Some other lines, although not selected in the list, had the same reactions to the races and may be used as substitute or in comparing with previous data. Chickpea lines ICC 7537 (W6-24873) and BG 212 (W6-24875) reacted to the five races in the same ways as CRIL7-1-17 and WR-315, respectively. We observed consistency of the differential reactions among replications in repeated trials. This concise set of differentials with vertical resistance to the races of $F$. oxysporum $\mathrm{f}$. sp. ciceris should save time and effort in future race differentiation, and the clear reactions of the differentials should eliminate or reduce ambiguous results in race determination. This set of differential lines will be maintained as a special collection and may be obtained on request from the website of the USDA-ARS National Plant Germplasm System.

\section{ACKNOWLEDGMENTS}

Biotechnology Overseas Associateship provided to Kamal Dev Sharma by the Department of Bio-
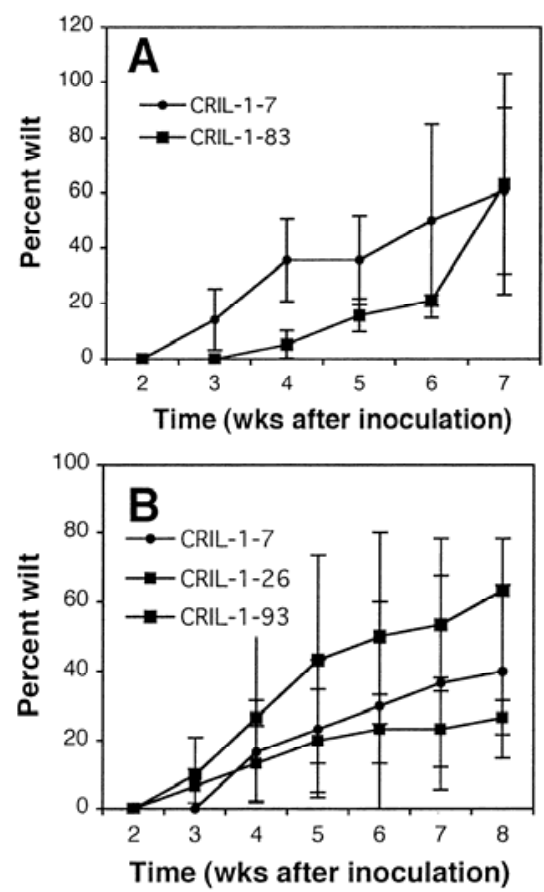

Fig. 3. Slow wilting responses of some chickpea $\mathrm{F}_{7}$ recombinant inbred lines (RILs) from a cross between WR-315 (resistant) and C-104 (susceptible) after inoculation with $\mathbf{A}$, race 2 or $\mathbf{B}$, race 3 of Fusarium oxysporum f. sp. ciceris. Each data point represents a mean \pm standard error $(n$ $=3$ ). 


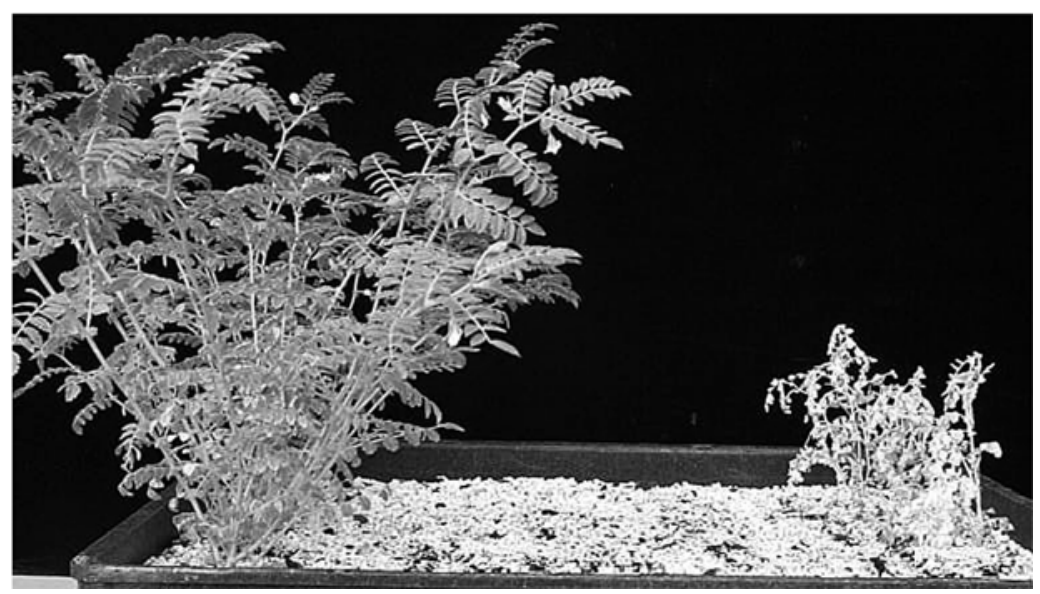

Fig. 4. Differential line CRIL-1-94 differentiates race 2 (right, susceptible) from race 3 (left, resistant) of Fusarium oxysporum f. sp. ciceris 4 weeks after inoculation.

technology, Ministry of Science and Technology, Government of India, is duly acknowledged. We also thank Clarice Coyne, USDA West Regional Plant Introduction Station, Washington State University, Pullman, for providing the seed of different chickpea lines.

\section{LITERATURE CITED}

1. Banyal, D. K., and Tyagi, P. D. 1997. Slow mildewing resistance in cultivar DPP-68 of garden pea in Himachal Pradesh, India. Int. J. Pest Manag. 43:193-196.

2. Barve, M. P., Haware, M. P., Sainani, M. N., Ranjekar, P. K., and Gupta, V. S. 2001. Potential of microsatellites to distinguish four races of Fusarium oxysporum f. sp. ciceri prevalent in India. Theor. Appl. Genet. 102:138-147.

3. El-Hadi, M. 1993. Studies on variability in morphology, pathogenicity and vegetative compatibility of Fusarium oxysporum f. sp. ciceris, and effect of inoculum density on chickpea wilt severity. M.Sc. thesis. Washington State University, Pullman

4. Gumber, R. K., Kumar, J., and Haware, M. P. 1995. Inheritance of resistance to fusarium wilt in chickpea. Plant Breed. 114:277-279.

5. Halila, M. H., and Strange, R. N. 1996. Identification of the casual agent of wilt of chickpea in Tunisia as Fusarium oxysporum f. sp. ciceri race 0. Phytopathol. Mediterr. 35:67-74.

6. Haware, M. P., and Nene, Y. L. 1982. Races of Fusarium oxysporum f. sp. ciceri. Plant Dis. 66:809-810.

7. Herath, I. H. M. H. B., Stoddard, F. L., and Marshall, D. R. 2001. Evaluating faba beans for rust resistance using detached leaves. Euphytica 117: 47-57.

8. Jalali, B. L., and Chand, H. 1992. Chickpea wilt. Pages 429-444 in: Plant Diseases of International Importance. Vol. 1. Diseases of Cereals and Pulses. U. S. Singh, A. N. Mukhopadhayay, J. Kumar, and H. S. Chaube, eds. Prentice Hall, Englewood Cliffs, NY.

9. Jimenez-Diaz, R. M., Alcala-Jimenez, A. R., Hervas, A., and Trapero-Casas, J. L. 1993.
Pathogenic variability and hosts resistance in the Fusarium oxysporum f. sp. ciceris/Cicer arietinum pathosystem. Pages 87-94 in: Proc. Eur. Semin. Fusarium Mycotoxins, Taxonomy, Pathogenicity and Host Resistance, 3rd Hodowsla Roslin Aklimatyazacja i Nasiennictwo. Plant Breeding and Acclimatization Institute, Radzikov, Poland.

10. Jimenez-Diaz, R. M., Trapero-Casas, A., and Cabrera de la Colina, J. 1989. Races of Fusarium oxysporum $\mathrm{f}$. sp. ciceris infecting chickpea in southern Spain. Pages 515-520 in: Vascular Wilt Diseases of Plants. E. C. Tjamos and C. H. Beckman, eds. NATO ASI Series, Vol. H28, Springer Verlag, Berlin.

11. Jimenez-Gasco, M. M., Perez-Artes, E., and Jimenez-Diaz, R. M. 2001. Identification of pathogenic races $0,1 \mathrm{~B} / \mathrm{C}, 5$ and 6 of Fusarium oxysporum f. sp. ciceris with random amplified polymorphic DNA (RAPD). Eur. J. Plant Pathol. 107:237-248.

12. Kelly, A. G., Alcala-Jimenez, A. R., Bainbridge, B. W., Heale, J. B., Perez-Artes, E., and Jimenez-Diaz, R. M. 1994. Use of genetic fingerprinting and random amplified polymorphic DNA to characterize pathotypes of Fusarium oxysporum f. sp. ciceris infecting chickpea. Phytopathology 84:1293-1298.

13. Kumar, J., and Haware, M. P. 1982. Inheritance of resistance to Fusarium wilt in chickpea. Phytopathology 72:1035-1036.

14. Kumar, S. 1998. Inheritance of resistance to Fusarium wilt (race 2) in chickpea. Plant Breed. 117:139-142.

15. Leonard, K. J. 2002. Oat lines with effective adult plant resistance to crown rust. Plant Dis. 86:593-598.

16. Mayer, M. S., Tullu, A., Simon, C. J., Kumar, J., Kaiser, W. J., Kraft, J. M., and Muehlbauer, F. J. 1997. Development of a DNA marker for fusarium wilt resistance in chickpea. Crop Sci. 37:1625-1629.

17. Nene, Y. L., Haware, M. P., Reddy, N. M. V., Philps, J. P., Castro, E. L., Kotasthane, S. R., Gupta, O., Singh, G., Shukia, P., and Sah, R. P.
1989. Identification of broad based and stable resistance to wilt and root-rots in chickpea. Indian Phytopathol. 42:499-505.

18. Phillips, J. C. 1988. A distinct race of chickpea wilt in California. Int. Chickpea Newsl. 18:19-20.

19. Rubio, J., Hajj-Moussa, E., Kharrat, M., Moreno, M. T., Millan, T., and Gill, J. 2003. Two genes and linked RAPD markers involved in resistance to Fusarium oxysporum f. sp. ciceris race 0 in chickpea. Plant Breed. 122:188-191.

20. Sharma, K. D., Winter, P., Kahl, G., and Muehlbauer, F. J. 2004. Molecular mapping of Fusarium oxysporum f. sp. ciceris race 3 resistance gene in chickpea. Theor. Appl. Genet. 108:1243-1248.

21. Singh, H., Kumar, J., Smithson, J. B., and Haware, M. P. 1987. Complementation between genes for resistance to race 1 of Fusarium oxysporum $\mathrm{f}$. sp. ciceri in chickpea. Plant Pathol. 36:539-543.

22. Singh, R. P., and Huerta, E. J. 2002. Effect of leaf rust resistance gene $\operatorname{Lr} 34$ on components of slow rusting at seven growth stages in wheat. Euphytica 129:371-376.

23. Sivaramakrishnan, S., Kannan, S., and Singh, S. D. 2002. Genetic variability of Fusarium wilt pathogen isolates of chickpea (Cicer arietinum L.) assessed by molecular markers. Mycopathologia 155:171-178.

24. Smith, B. M., Crowther, T. C., Clarkson, J. P., and Trueman, L. 2000. Partial resistance to rust (Puccinia allii) in cultivated leek (Allium ampeloprasum ssp. porrum): Estimation and improvement. Ann. Appl. Biol. 137:43-51.

25. Tekeoglu, M., Tullu, A., Kaiser, W. J., and Muehlbauer, F. J. 2000. Inheritance and linkage of two genes that confer resistance to Fusarium wilt in chickpea. Crop Sci. 40:12471251.

26. Tullu, A. 1996. Genetics of fusarium wilt resistance in chickpea. Ph.D. diss. Washington State University, Pullman.

27. Tullu, A., Kaiser, W. J., Kraft, J. M., and Muehlbauer, F. J. 1999. A second gene for resistance to race 4 of Fusarium wilt in chickpea and linkage with a RAPD marker. Euphytica 109:43-50.

28. Tullu, A., Muehlbauer, F. J., Simon, C. J., Mayer, M. S., Kumar, J., Kaiser, W. J., and Kraft, J. M. 1998. Inheritance and linkage of a gene for resistance to race 4 of fusarium wilt and RAPD markers in chickpea. Euphytica 102:227-232.

29. Upadhyaya, H. D., Haware, M. P., Kumar, J., and Smithson, J. B. 1983. Resistance to wilt in chickpea. I. Inheritance of late wilting in response to race 1. Euphytica 32:447-452.

30. Upadhyaya, H. D., Smithson, J. B., Haware, M. P., and Kumar, J. 1983. Resistance to wilt in chickpea. II. Further evidence for two genes for resistance to race 1. Euphytica 32:749-755.

31. Westerlund, F. V., Campbell, R. N., and Kimble, K. A. 1974. Fungal root rot and wilt of chickpea in California. Phytopathology 64:632-635.

32. Yaege, J. R., and Stuteville, D. L. 2002. Reactions of accessions in the annual Medicago core germ plasm collection to Erysiphe pisi. Plant Dis. 86: 312-315. 